\title{
HUBUNGAN LAMA SAKIT, PENGETAHUAN, MOTIVASI PASIEN DAN DUKUNGAN KELUARGA DENGAN KEPATUHAN DIET PASIEN DIABETES MELLITUS
}

\author{
Bertalina $^{1}$, Purnama ${ }^{2}$ \\ ${ }^{1,2}$ Jurusan Gizi, Poltekkes Tanjungkarang \\ Email: ubertalina@yahoo.com
}

\begin{abstract}
Relationships a Long Illness, Knowledge, Motivation Patient and Family Support with Dietary Compliance of Patients Diabetes Mellitus. Age-related prevalence of diabetes increased from $5.9 \%$ to $7.1 \%$ (246-380 people) around the world in the age group 20-79 years increased by $55 \%$ incidence. The purpose of this research is knowing the relationship a long illness, knowledge, patient motivation, and family support with dietary compliance of patients Diabetes Mellitus. This research is an analytic research with cross sectional method, conducted in June 2016. Based on the research results, the distribution of the characteristics of the respondent, it is known that the majority were female sex (56.7\%), most respondents age range 51-60 years $(43.3 \%)$, and most respondents last education is high school $(36,7 \%)$. Most respondents were housewives $(46.7 \%)$ and the majority of respondents had nutritional counseling (63.3\%). Distribution of respondents with disease duration of less than 5 years was $50 \%$. Respondents mostly good knowledge $(66.7 \%)$, have poor motivation $(53.3 \%)$ and has the support of family support $(66.7 \%)$. Statistical test results that there is no relationship between long illness with diet compliance in patients with DM. There is a relationship between knowledge, motivation of the patient and family support with diet compliance in patients with DM.
\end{abstract}

Keywords: Diabetes Mellitus, Patients, Diet

\begin{abstract}
Abstrak: Hubungan Lama Sakit, Pengetahuan, Motivasi Pasien dan Dukungan Keluarga Dengan Kepatuhan Diet Pasien Diabetes Mellitus. Prevalensi diabetes terkait usia meningkat dari 5,9\% sampai 7,1\% (246-380 jiwa) di seluruh dunia pada kelompok usia 20-79 tahun yang kejadiannya meningkat 55\%. Tujuan dari penelitian ini adalah diketahuinya hubungan lama sakit, pengetahuan, motivasi pasien, dan dukungan keluarga dengan kepatuhan diet pasien Diabetes Mellitus. Penelitian ini merupakan penelitian analitik dengan metode cross sectional yang dilakukan pada bulan Juni 2016. Berdasarkan hasil penelitian, diperoleh hasil analisis univariat distribusi karakteristik responden, diketahui bahwa jenis kelamin terbanyak adalah perempuan $(56,7 \%)$, umur responden terbanyak berkisar 51-60 tahun $(43,3 \%)$ dan pendidikan terakhir responden terbanyak adalah SMA $(36,7 \%)$. Pekerjaan terbanyak responden adalah ibu rumah tangga $(46,7 \%)$ dan sebagian besar responden pernah melakukan konsultasi gizi (63,3\%). Distribusi responden dengan lama sakit kurang dari 5 tahun adalah 50\%. Responden sebagian besar pengetahuan yang baik $(66,7 \%)$, memiliki motivasi yang kurang baik $(53,3 \%)$ dan memiliki dukungan keluarga yang mendukung $(66,7 \%)$. Hasil uji statistik yaitu tidak ada hubungan antara lama sakit dengan kepatuhan diet pada pasien DM. Ada hubungan antara pengetahuan, motivasi pasien serta dukungan keluarga dengan kepatuhan diet pada pasien DM.
\end{abstract}

Kata kunci: Diabetes Mellitus, Pasien, Diet

Diabetes Mellitus merupakan kondisi kronis yang ditandai dengan peningkatan konsentrasi glukosa darah disertai munculnya gejala yang khas, yakni urin yang berasa manis dalam jumlah yang besar. Kelainan yang menjadi penyebab mendasar dari Diabetes Mellitus adalah defisiensi relatif atau absolut dari hormon insulin. Insulin merupakan satu-satunya hormon yang dapat menurunkan kadar glukosa dalam darah. Terdapat dua kategori diabetes, yaitu diabetes tipe 1 yang terjadi akibat penghancuran autoimun dari sel $\beta$ penghasil insulin di pulau Langerhans pada pankreas (defisiensi absolut) dan diabetes tipe 2 yang merupakan dampak dari gangguan sekresi insulin dan resistensi terhadap kerja insulin yang sering kali disebabkan oleh obesitas (defisiensi relatif) (Bilous dan Donelly, 2014).

Diabetes apabila tidak dikelola dengan baik akan dapat mengakibatkan terjadinya berbagai penyulut menahun, seperti penyeakit serebro-vaskular, penyakit jantung koroner, penyakit pembuluh darah tungkai, penyulit pada mata, ginjal dan syaraf. Jika kadar glukosa darah dapat selalu dikendalikan dengan baik, 
diharapkan semua penyulit menahun tersebut dapat dicegah, paling tidak sedikit dihambat. Kasus diabetes terbanyak dijumpai adalah DM tipe 2, yang umumnya mempunyai latar belakang kelainan berupa resistensi insulin (Suyono, 2015).

Diabetes Mellitus menjadi masalah
karena
kesehatan masyarakat utama karena komplikasinya yang bersifat jangka pendek dan jangka panjang. Komplikasi diabetes terhadap sistem vaskular kecil seperti mata, ginjal, dan saraf. Terhadap sitem vaskular besar berkontribusi terhadap perkembangan angka kesakitan, bahkan peningkatan angka kematian. Defisiensi absolut dari insulin menyebabkan keroasidosis dan koma yang diikuti dengan kematian, bahkan di Inggris ataupun negara maju lainnya. Diabetes menjadi penyakit yang semakin tren saat ini. Prevalensi diabetes terkait usia meningkat dari $5,9 \%$ sampai $7,1 \% \quad(246-380$ jiwa) di seluruh dunia pada kelompok usia 20-79 tahun yang kejadiannya meningkat 55\%. Proporsi dari diabetes tipe 1 sampai tipe 2 bervariasi dari 15:85 pada populasi di negara maju samapai 5:95 pada populasi di negara berkembang (Bilous dan Donelly, 2014).

Estimasi terakhir IDF, terdapat 382 juta orang yang hidup dengan diabetes di dunia pada tahun 2013. Pada tahun 2035 jumlah tersebut diperkirakan akan meningkat menjadi 592 juta orang. Diperkirakan dari 382 juta orang tersebut, 175 juta di antaranya belum terdiagnosis, sehingga terancam berkembang progresif menjadi komplikasi tanpa disadari dan tanpa dicegah (Kemenkes RI, 2014).

Prevalensi penderita Diabetes Mellitus di Indonesia pada tahun 2013 mencapai 5,8\% atau sekitar 8,5 juta penduduk dengan rentang usia 2079 tahun. (Kemenkes, 2014). Jumlah penderita DM (kencing manis) di Indonesia terus meningkat menempati urutan keempat terbesar di dunia setelah India, China, dan Amerika Serikat (Hiswani, 2010).

Prevalensi Diabetes Mellitus di Provinsi Lampung pada tahun 2013 sebesar 0,8\%. Sedangkan prevalensi untuk kota Bandarlampung yaitu $0,9 \%$ menempati urutan ke lima se Provinsi Lampung. Populasi yang menderita DM tipe 2 di kota Bandarlampung berdasarkan laporan enam bulanan yang didapatkan sebanyak 2032 orang dengan rata-rata per bulan 339 orang dengan usia $\geq 40$ tahun (Dinkes Kota Bandarlampung, 2014). Jumlah pasien Diabetes Mellitus rawat jalan di RSUD Abdul Moeloek menempati urutan ke-2 dari 10 penyakit terbanyak dengan jumlah pengunjung 6.972 pengunjung pada tahun 2013, 4.248 pengunjung pada tahun 2011 dan 5.744 pengunjung pada tahun 2010 (Ferdiansyah, 2014). Pada tahun 2014 jumlah pasien rawat jalan Diabetes Mellitus di Poli Penyakit Dalam RSUD Abdul Moeloek adalah 896 pasien. Pada tahun 2015 jumlah pasien rawat jalan Diabetes Mellitus adalah 731 pasien yang terdiri dari 490 pasien Diabetes Mellitus tipe 2 dan 241 pasien Diabetes Mellitus tipe 1 (Rekam Medik RSUD Abdul Moeloek, 2016).

Salah satu faktor risiko utama yang mempengaruhi terjadinya DM adalah pola makan yang tidak sehat dimana mereka cenderung terus menerus mengkonsumsi karbohidrat dan makanan sumber glukosa secara berlebihan, sehingga dapat menaikan kadar glukosa darah sehingga perlu adanya pengaturan diet bagi pasien DM dalam mengkonsumsi makanan dan diterapkan dalam kebiasaan makan sehari-hari sesuai kebutuhan tubuh. Tidaklah mudah mengatur pola makan bagi pasien DM, karena pasti akan timbul kejenuhan bagi pasien DM karena menu yang dikonsumsi serba dibatasi sehingga diperlukan adanya motivasi bagi pasien untuk dapat mengontrol glukosa darah dengan cara mengatur pola makan (Indarwati dkk, 2012). Sangat sulit menilai tingkat kepatuhan penderita dalam mengikuti anjuran dokter untuk dapat mengendalikan kadar glukosa darah, baik menyangkut jadwal minum obat dan dosis, maupun pola hidup (pola makan, olah raga, dan lain-lain).

Kepatuhan diit dalam perencanaan makan banyak dipengaruhi oleh beberapa faktor antara seperti pendidikan, akomodasi, perubahan model terapi, modifikasi faktor lingkungan dan sosial, serta meningkatkan interaksi profesional tenaga kesehatan dengan pasien. Modifikasi faktor lingkungan dapat dibangun melalui dukungan sosial dari keluarga. Motivasi sangat penting peranannya karena dengan motivasi mampu membuat seseorang melakukan sesuatu untuk mencapai tujuan yang diinginkan (Indarwati dkk, 2012). Berdasarkan penelitian yang dilakukan oleh Gustina dkk (2014), bahwa faktor-faktor yang mempengaruhi kepatuhan diet pada penderita Diabetes Mellitus adalah motivasi pasien dan dukungan keluarga.

Menurut laporan WHO pada tahun 2003, kepatuhan rata-rata pasien pada terapi jangka panjang terhadap penyakit kronis di negara maju hanya sebesar $50 \%$ sedangkan di negara berkembang jumlah tersebut bahkan lebih rendah. Kepatuhan pasien sangat diperlukan untuk mencapai keberhasilan terapi terutama pada penyakit yang tidak menular seperti penyakit Diabetes Mellitus dan penyakit lainnya. Ketidakpatuhan pasien pada terapi penyakit 
Diabetes Mellitus dapat memberikan efek negatif yang sangat besar karena presentase kasus penyakit tidak menular tersebut diseluruh dunia mencapai $54 \%$ dari seluruh penyakit pada tahun 2001. Angka ini bahkan diperkirakan akan meningkat menjadi lebih dari $65 \%$ pada tahun 2020.

Periode sakit dapat mempengaruhi kepatuhan. Beberapa penyakit yang tergolong penyakit kronik, banyak mengalami masalah kepatuhan.

Motivasi adalah suatu proses dalam diri manusia yang menyebabkan organisme tersebut bergerak menuju tujuan yang dimiliki, atau bergerak menjauh dari situasi yang tidak menyenangkan (Wade dan Travis, 2007). Sikap perilaku dalam kesehatan individu juga dipengaruhi oleh motivasi diri individu untuk berperilaku yang sehat dan menjaga kesehatan. Tanpa motivasi dalam pengaturan diet pasien DM akan mengalami ketidakpatuhan dalam mengatur pola makan sehari-hari. Kepatuhan pasien DM dalam melaksanakan diet merupakan salah satu hal terpenting dalam pengendalian DM. Pasien DM harus bisa mengatur pola makannya sesuai dengan prinsip diet DM yang dianjurkan oleh tenaga kesehatan, karena dengan mengatur pola makan pasien bisa mempertahankan gula darah mereka agar tetap terkontrol (Indarwati dkk, 2012).

Kendala utama pada penanganan diet Diabetes Mellitus adalah kejenuhan pasien dalam mengikuti terapi diet yang sangat diperlukan untuk mencapai keberhasilan. Pelaksanaan diet Diabetes Mellitus sangat dipengaruhi oleh adanya dukungan dari keluarga. Dukungan dapat digambarkan sebagai perasaan memiliki atau keyakinan bahwa seseorang merupakan peserta aktif dalam kegiatan sehari-hari. Perasaan saling terikat dengan orang lain di lingkungan menimbulkan kekuatan dan membantu menurunkan perasaan terisolasi (Brunner dan Suddart, 2002). Jika dukungan keluarga tidak ada maka pasien Diabetes Mellitus akan tidak patuh dalam pelaksanaan diet, sehingga penyakit Diabetes Mellitus tidak terkendali dan terjadi komplikasi yaitu penyakit jantung, ginjal, kebutaan, ateroskleorosis, bahkan sebagian tubuh dapat diamputasi. Dan apabila dukungan keluarga baik maka pasien Diabetes Mellitus akan patuh dalam pelaksanaan diet, sehingga penyakit Diabetes Mellitus terkendali (Rahmat, 2002).

Berdasarkan latar belakang permasalahan di atas peneliti tertarik untuk mengetahui hubungan lama sakit, pengetahuan, motivasi pasien dan dukungan keluarga terhadap kepatuhan diet pada pasien Diabetes Mellitus.

\section{METODE PENELITIAN}

Rancangan penelitian ini menggunakan penelitian secara analitik dengan pendekatan cross sectional. Karena penelitian ini dilakukan hanya satu kali pada saat yang bersamaan.

Dalam penggunaan studi cross sectional pengukuran variabel dependen (kepatuhan diet) dan variabel independen (lama sakit, pengetahuan dan motivasi pasien, dukungan keluarga,)dilakukan pada waktu yang bersamaan dan secara langsung.

Populasi pada penelitian ini adalah pasien Diabetes Mellitus tipe 2 di Poli Penyakit Dalam RSUD Abdul Moeloek dengan jumlah pengunjung 731 dalam satu tahun dengan ratarata 43 pengunjung setiap bulannya. Sampel penelitian ini adalah adalah pasien Diabetes Mellitus tipe 2 di Poli Penyakit Dalam RSUD Abdul Moeloek. Sampel pada penelitian ini ditentukan berdasarkan pertimbangan peneliti dengan menggunakan kriteria inklusi, yang berjumlah 100 orang.

\section{HASIL}

\section{A. ANALISIS UNIVARIAT}

\section{Lama Sakit}

Distribusi responden berdasarkan lama sakitnya dapat dilihat pada tabel 1 .

\section{Tabel 1. Distribusi Frekuensi Pasien Diabetes Mellitus Berdasarkan Lama Sakit}

\begin{tabular}{ccc}
\hline \multirow{2}{*}{ Lama Sakit } & \multicolumn{2}{c}{ Jumlah Responden } \\
\cline { 2 - 3 } & $\mathbf{n}$ & $\mathbf{\%}$ \\
\hline$<5$ Tahun & 15 & 50 \\
\hline$\geq 5$ Tahun & 15 & 50 \\
\hline Jumlah & $\mathbf{3 0}$ & $\mathbf{1 0 0}$ \\
\hline
\end{tabular}

Berdasarkan tabel diketahui bahwa jumlah responden yang telah menderita Diabetes Mellitus <5 tahun sebanding dengan yang lebih dari 5 tahun yaitu masing-masing 50\%.

\section{Pengetahuan}

Distribusi frekuensi pasien Diabetes Mellitus berdasarkan tingkat pengetahuannya dapat dilihat pada tabel 2 . 
Tabel 2. Distribusi Frekuensi Pasien Diabetes Mellitus Berdasarkan Pengetahuan

\begin{tabular}{ccc}
\hline \multirow{2}{*}{ Pengetahuan } & \multicolumn{2}{c}{ Jumlah Responden } \\
\cline { 2 - 3 } & $\mathbf{n}$ & $\mathbf{\%}$ \\
\hline Kurang baik & 10 & 33,3 \\
\hline Baik & 20 & 66,7 \\
\hline Jumlah & $\mathbf{3 0}$ & $\mathbf{1 0 0}$ \\
\hline
\end{tabular}

Berdasarkan tabel dapat diketahui bahwa sebagian besar responden telah memiliki pengetahuan yang cukup baik yaitu sebesar $66,7 \%$ sedangkan responden yang pengetahuannya kurang baik hanya $33,3 \%$.

\section{Motivasi}

Distribusi frekuensi pasien berdasarkan motivasi dapat dilihat pada tabel 3 .

Tabel 3. Distribusi Frekuensi Pasien Diabetes Mellitus Berdasarkan Motivasi Pasien

\begin{tabular}{lcc}
\hline \multirow{2}{*}{ Motivasi } & \multicolumn{2}{c}{ Jumlah Responden } \\
\cline { 2 - 3 } & $\mathbf{n}$ & $\mathbf{\%}$ \\
\hline Kurang baik & 16 & 53,3 \\
\hline Baik & 14 & 46,7 \\
\hline Jumlah & $\mathbf{3 0}$ & $\mathbf{1 0 0}$ \\
\hline
\end{tabular}

Berdasarkan tabel di atas dapat diketahui bahwa lebih banyak responden yang memiliki motivasi kurang baik yaitu sebesar 53,3\%. Sedangkan responden yang memiliki motivasi yang baik adalah sebesar $46,7 \%$.

\section{Dukungan Keluarga}

Distribusi frekuensi dukungan keluarga responden dapat dilihat pada tabel 4.

Tabel 4. Distribusi Frekuensi Pasien Diabetes Mellitus Berdasarkan Dukungan Keluarga

\begin{tabular}{ccc}
\hline Dukungan & \multicolumn{2}{c}{ Jumlah Responden } \\
\cline { 2 - 3 } Keluarga & $\mathbf{n}$ & $\mathbf{\%}$ \\
\hline $\begin{array}{l}\text { Kurang } \\
\text { mendukung }\end{array}$ & 10 & 33,3 \\
\hline Mendukung & 20 & 66,7 \\
\hline Jumlah & $\mathbf{3 0}$ & $\mathbf{1 0 0}$ \\
\hline
\end{tabular}

Berdasarkan tabel di atas dapat diketahui bahwa sebagian besar pasien Diabetes Mellitus mendapat dukungan keluarga yang mendukung yaitu sebesar $66,7 \%$ sedangkan pasien dengan dukungan keluarga yang kurang mendukung hanya sekitar 33,3\%.

\section{Kepatuhan Diet}

Distribusi frekuensi pasien berdasarkan kepatuhan terhadap diet Diabetes Mellitus dapat dilihat pada tabel 5 .

Tabel 5. Distribusi Frekuensi Pasien Diabetes Mellitus Berdasarkan Kepatuhan Diet

\begin{tabular}{ccc}
\hline \multirow{2}{*}{ Kepatuhan Diet } & \multicolumn{2}{c}{ Jumlah Responden } \\
\cline { 2 - 3 } & $\mathbf{n}$ & $\mathbf{\%}$ \\
\hline Tidak patuh & 18 & 60 \\
\hline Patuh & 12 & 40 \\
\hline Jumlah & $\mathbf{3 0}$ & $\mathbf{1 0 0}$ \\
\hline
\end{tabular}

Berdasarkan tabel di atas dapat diketahui bahwa masih banyak pasien Diabetes Mellitus yang tidak patuh dalam pelaksanaan diet yaitu sebesar 60\% sedangkan yang patuh dalam melaksanakan diet Diabetes Mellitus adalah sebesar $40 \%$.

\section{B. ANALISIS BIVARIAT}

\section{Hubungan Lama Sakit dengan Kepatuhan Diet}

Tabel 6. Hubungan Lama Sakit dengan Kepatuhan Diet Pasien Diabetes Mellitus

\begin{tabular}{|c|c|c|c|c|c|c|c|c|}
\hline \multirow{3}{*}{ No. } & \multirow{3}{*}{$\begin{array}{r}\text { Lama } \\
\text { Sakit }\end{array}$} & \multicolumn{4}{|c|}{ Kepatuhan Diet } & \multirow{2}{*}{\multicolumn{2}{|c|}{ Total }} & \multirow{3}{*}{$\begin{array}{c}p- \\
\text { value }\end{array}$} \\
\hline & & \multicolumn{2}{|c|}{$\begin{array}{l}\text { Tidak } \\
\text { Patuh }\end{array}$} & \multicolumn{2}{|c|}{ Patuh } & & & \\
\hline & & $\mathbf{n}$ & $\%$ & $\mathbf{n}$ & $\%$ & $\mathbf{n}$ & $\%$ & \\
\hline 1 & $\begin{array}{l}<5 \\
\text { tahun }\end{array}$ & 10 & 66,7 & 5 & 33,3 & 15 & 100 & \\
\hline 2 & $\begin{array}{l}\geq 5 \\
\text { tahun }\end{array}$ & 8 & 53,3 & 7 & 44,7 & 15 & 100 & 0,709 \\
\hline
\end{tabular}

Berdasarkan tabel di atas dapat diketahui bahwa sebanyak $33,3 \%$ responden yang memiliki lama sakit kurang dari 5 tahun patuh terhadap diet sedangkan yang lebih dari 5 tahun sebanyak $41,7 \%$ yang patuh terhadap diet.

Hasil uji chi square menunjukkan tidak adanya hubungan yang bermakna antara lama sakit dengan kepatuhan diet pada pasien Diabetes Mellitus dengan nilai $p=0,709(p<0,05)$ 


\section{Hubungan Pengetahuan dengan 4. Hubungan Dukungan Keluarga dengan Kepatuhan Diet Kepatuhan Diet}

Tabel 7. Hubungan Pengetahuan dengan

Tabel 9. Hubungan Dukungan Keluarga Kepatuhan Diet Pasien Diabetes dengan Kepatuhan Diet Pasien Mellitus Diabetes Mellitus

\begin{tabular}{|c|c|c|c|c|c|c|c|}
\hline \multirow{3}{*}{$\begin{array}{l}\text { Penge- } \\
\text { tahu- } \\
\text { an }\end{array}$} & \multicolumn{4}{|c|}{ Kepatuhan Diet } & \multirow{2}{*}{\multicolumn{2}{|c|}{ Total }} & \multirow{3}{*}{$\begin{array}{c}p- \\
\text { value }\end{array}$} \\
\hline & \multicolumn{2}{|c|}{$\begin{array}{l}\text { Tidak } \\
\text { Patuh }\end{array}$} & \multicolumn{2}{|c|}{ Patuh } & & & \\
\hline & $\mathbf{n}$ & $\%$ & n & $\%$ & $\mathbf{n}$ & $\%$ & \\
\hline $\begin{array}{l}\text { Kurang } \\
\text { baik }\end{array}$ & 10 & 100 & 0 & 0 & 10 & 100 & \\
\hline Baik & 8 & 40 & 12 & 60 & 20 & 100 & \\
\hline Jumlah & 18 & 60 & 12 & 40 & 30 & 100 & \\
\hline
\end{tabular}

\begin{tabular}{lccccccc}
\hline \multirow{2}{*}{$\begin{array}{c}\text { Dukungan } \\
\text { Keluarga }\end{array}$} & \multicolumn{4}{l}{ Kepatuhan Diet } & & & \\
\cline { 2 - 5 } & $\begin{array}{c}\text { Tidak } \\
\text { Patuh }\end{array}$ & \multicolumn{2}{c}{ Patuh } & Total & $\begin{array}{c}\boldsymbol{p} \text { - } \\
\text { value }\end{array}$ \\
\cline { 2 - 7 } & $\mathbf{n}$ & $\mathbf{\%}$ & $\mathbf{n}$ & $\mathbf{\%}$ & $\mathbf{n}$ & $\mathbf{\%}$ & \\
\hline $\begin{array}{l}\text { Kurang } \\
\text { mendukung }\end{array}$ & 10 & 100 & 0 & 0 & 10 & 100 & \\
\hline Mendukung & 8 & 40 & 12 & 60 & 20 & 100 & 0,002 \\
\hline Jumlah & $\mathbf{1 8}$ & $\mathbf{6 0}$ & $\mathbf{1 2}$ & $\mathbf{4 0}$ & $\mathbf{3 0}$ & $\mathbf{1 0 0}$ & \\
\hline
\end{tabular}

Berdasarkan tabel di atas dapat diketahui bahwa pasien Diabetes Mellitus yang patuh terhadap diet sebanyak $60 \%$ dengan pengetahuan yang baik dan tidak ada yang berpengetahuan kurang.

Hasil uji Fisher menunjukkan adanya hubungan yang bermakna antara tingkat pengetahuan dengan kepatuhan diet pada pasien Diabetes Mellitus dengan nilai $p=0,002$ $(p<0,05)$.

\section{Hubungan Motivasi Pasien dengan Kepatuhan Diet}

Tabel 8. Hubungan Motivasi Pasien dengan Kepatuhan Diet Pasien Diabetes Mellitus

\begin{tabular}{|c|c|c|c|c|c|c|c|}
\hline \multirow{3}{*}{ Motivasi } & \multicolumn{4}{|c|}{ Kepatuhan Diet } & \multirow{2}{*}{\multicolumn{2}{|c|}{ Total }} & \multirow{3}{*}{$\begin{array}{c}p- \\
\text { value }\end{array}$} \\
\hline & \multicolumn{2}{|c|}{$\begin{array}{l}\text { Tidak } \\
\text { Patuh }\end{array}$} & \multicolumn{2}{|c|}{ Patuh } & & & \\
\hline & $\mathbf{n}$ & $\%$ & $\mathbf{n}$ & $\%$ & $\mathbf{n}$ & $\%$ & \\
\hline $\begin{array}{l}\text { Kurang } \\
\text { baik }\end{array}$ & 14 & 77,8 & 2 & 16,7 & 16 & 100 & \\
\hline Baik & 4 & 22,2 & 10 & 83,3 & 14 & 100 &, 0 \\
\hline Jumlah & 18 & 60 & 12 & 40 & 30 & 100 & \\
\hline
\end{tabular}

Berdasarkan tabel di atas dapat diketahui bahwa sebanyak $16,7 \%$ responden yang memiliki motivasi yang kurang baik yang patuh terhadap diet sedangkan sebanyak $83,3 \%$ responden yang memiliki motivasi yang baik dan patuh terhadap diet.

Hasil uji chi square menunjukkan adanya hubungan yang bermakna antara motivasi pasien dengan kepatuhan diet pada pasien Diabetes Mellitus dengan nilai $\mathrm{p}=0,004(\mathrm{p}<0,05)$.

\section{PEMBAHASAN}

\section{a. Gambaran Lama Sakit Pasien Diabetes Mellitus}

Lama sakit ini berhubungan dengan usia pertama kali penderita terdiagnosa Diabetes Mellitus, semakin muda usia penderita terdiagnosa Diabetes Mellitus maka semakin lama penderita akan menanggung sakit dan saat ini menurut Syafputri (2012) penyakit Diabetes Mellitus tipe II mulai banyak menyerang kaum usia muda penyakit Diabetes Mellitus tipe II mulai banyak menyerang kaum usia muda. Hal ini dapat terjadi karena perubahan gaya hidup, serta menyangkut kecenderungan mengonsumsi makanan yang kurang serat ditambah dengan minuman yang banyak mengandung glukosa. Selain itu, kurangnya aktivitas yang membakar lemak atau kurang gerak.

Berdasarkan tabel diketahui bahwa jumlah responden yang telah menderita Diabetes Mellitus <5 tahun sebanding dengan yang lebih dari 5 tahun yaitu masing-masing 15 orang.

Diabetes dapat menimpa usia berapa saja, meski paling banyak menimpa orang berusia di atas 40 tahun. Tetapi, karena perubahan gaya hidup modern yang kurang sehat membuat prevalensi penderita diabetes berusia 20 tahun atau 30 tahun dan depresi berdampingan dengan penyakit berat atau merupakan reaksi terhadap penyakit dan pada beberapa orang, penyakit kronis dapat menyebabkan depresi. Penyakit kronis adalah penyakit yang berlangsung dalam 
waktu yang lama dan biasanya tidak dapat disembuhkan sepenuhnya. Walau begitu, penyakit kronis sering dapat dikendalikan melalui diet, olahraga, kebiasaan gaya hidup, dan obatobatan tertentu (Syafputri, 2012).

\section{b. Gambaran Pengetahuan Pasien Diabetes Mellitus}

Pengetahuan adalah hasil pengindraan manusia atau hasil tahu seseorang terhadap objek melalui indra yang dimilkinya (mata, hidung, telinga, dan sebagainya). Dengan sendirinya pada waktu pengindraan sehingga menghasilkan pengetahuan tersebut sangat dipengaruhi oleh intensitas perhatian dan persepsi terhadap objek. Pengetahuan merupakan sesuatu yang diketahui oleh seseorang dengan jalan apapun dan sesuatu yang diketahui orang dari pengalaman yang didapat. Sebagian besar pengetahuan seseorang diperoleh melalui indera pendengaran (telinga) dan indera penglihatan (Notoatmodjo, 2010).

Berdasarkan data yang diperoleh peneliti terhadap 30 orang pasien Diabetes Mellitus di Poli Penyakit Dalam RSUD Dr. H. Abdul Moeloek diketahui bahwa responden yang memiliki pengetahuan yang cukup baik yaitu sebesar $66,7 \%$ sedangkan responden yang pengetahuannya kurang baik hanya $33,3 \%$. Pengetahuan pasien yang baik lebih besar daripada pasien yang memiliki tingkat pengetahuan yang kurang baik.

Dari penelitian yang dilakukan, responden dengan pengetahuan yang kurang (33,3\%) sebagian besar belum memahami tentang penatalaksanaan Diabetes Mellitus dan prinsip diet diabetes yaitu $3 \mathrm{~J}$ (tepat jumlah, jadwal, dan jenis makanan) terutama dalam pemilihan jenis makanan yang tepat bagi penderita Diabetes Mellitus. Selain itu, pengetahuan yang kurang baik ditunjukkan dengan responden yang belum mengerti tanda kadar gula darah dibawah normal yaitu lemas, pucat, gemetar, merasa lapar, jantung berdebar-debar dan keringat berlebih. Responden menganggap bahwa kadar gula tinggi merupakan kelebihan gula dalam tubuh yang disebabkan oleh sering mengkonsumsi makanan yang manis dan tidak mengetahui jenis-jenis makanan sumber karbohidrat yang dapat menaikkan gula darah dengan cepat. Selain itu masih banyak responden juga masih belum mengerti bagaimana pertolongan pertama saat gula darah sedang rendah.

Berdasarkan hasil penelitian dapat diketahui bahwa mayoritas responden berusia di bawah 65 tahun dan mayoritas responden tersebut memiliki pengetahuan yang baik. Semakin tua usia seseorang maka proses perkembangan mentalnya bertambah baik, akan tetapi pada umur tertentu bertambahnya proses perkembangan mental tidak secepat seperti ketika berumur belasan tahun. Akan tetapi ketika penderita Diabetes Mellitus yang telah mempunyai usia lebih dari 65 tahun cenderung tidak mudah untuk menerima perkembangan/informasi baru yang menunjang derajat kesehatannya. Hal ini dikarenakan proses berpikir yang dimiliki oleh responden mengalami penurunan dalam hal mengingat dan menerima sesuatu hal yang baru. Seorang penderita Diabetes Mellitus yang telah berumur lebih dari 65 tahun akan menurunkan pengetahuan responden itu sendiri (Smeltzer \& Bare, 2002 dalam Cahyati, 2015).

Berdasarkan tabel 6 dapat diketahui bahwa mayoritas responden memiliki pendidikan yang tinggi yaitu SMA dan Perguruan Tinggi. Pendidikan merupakan suatu proses yang akan menghasilkan perubahan perilaku seseorang yang berbentuk peningkatan kemampuan kognitif, afektif dan psikomotor (Notoatmodjo, 2003). Menurut Nursalam (2011) semakin tinggi tingkat pendidikan seseorang maka semakin mudah orang tersebut menerima informasi, sehingga banyak pula pengetahuan yang dimiliki. Meskipun dengan tingkat pendidikan menengah memungkinkan seseorang memiliki pengetahuan yang baik karena informasi selain diperoleh dari pendidikan formal juga bisa diperoleh dari pendidikan non formal ataupun informasi yang didapat dari media massa maupun media elektronik.

Hasil penelitian ini sejalan dengan penelitian yang dilakukan oleh Cahyati (2015) tentang hubungan tingkat pengetahuan dengan tingkat kepatuhan diet DM , dimana sebagian responden memiliki pengetahuan yang baik yaitu $75,7 \%$. Sedangkan responden dengan pengetahuan yang cukup sebanyak 21,6\% dan yang memiliki pengetahuan yang kurang hanya $2,7 \%$. Menurutnya, pengetahuan yang kurang disebabkan oleh umur, jenis kelamin, dan pekerjaan responden.

Hal ini kemungkinan besar disebabkan oleh kurang terpaparnya informasi mengenai penyakit Diabetes Mellitus oleh responden dan bagaimana cara pengaturan makan/diet yang seharusnya dilaksanakan. Kurangnya minat pasien untuk mengikuti konsultasi dari ahli gizi juga mempengaruhi pengetahuan responden. Dari hasil wawancara dengan responden, diketahui bahwa responden jarang melakukan konseling ke Poli Gizi setelah melakukan cek kadar gula darah. Bahkan masih ada 36,7\% responden yang 
belum pernah melakukan konseling gizi sebelumnya.

Rumah Sakit diharapkan meningkatkan kerjasama antara dokter dan ahli gizi untuk meningkatkan pengetahuan dan kesadaran pasien dengan mengadakan penyuluhan gizi khususnya untuk pasien Diabetes Mellitus tipe 2 dalam pengaturan makan serta merujuk pasien Diabetes Mellitus ke Poli Gizi apabila pengetahuan pasien terkait pengaturan makan masih dirasa kurang. Selain itu diperlukan peran ahli gizi untuk lebih aktif dalam memberikan pelayanan pada saat konsultasi gizi sehingga pasien berminat untuk datang ke konsultasi gizi.

\section{c. Gambaran Motivasi Pasien Diabetes Mellitus}

Berdasarkan penelitian yang dilakukan di ruangan Poli Penyakit Dalam RSUD Dr. H. Abdul Moeloek terhadap pasien rawat jalan diabetes dapat diketahui bahwa responden yang memiliki motivasi rendah yaitu sebesar 53,3\%. Sedangkan responden yang memiliki motivasi tinggi adalah sebesar $46,7 \%$.

Dari hasil wawancara responden diketahui bahwa lebih banyak responden $(53,3 \%)$ yang memiliki motivasi diri yang kurang. Hal ini mungkin dikarenakan kurangnya kepercayaan pada diri sendiri serta merasa kesulitan dalam menjalankan diet yang dianjurkan oleh ahli gizi. Responden lebih percaya bahwa kadar gula darah dapat terkontrol dengan baik hanya dengan mengonsumsi obat-obatan yang diresepkan oleh petugas kesehatan. Sebaliknya, menjaga pola makan serta beraktivitas bukan merupakan hal yang penting untuk menjaga kadar gula darah tetap normal. Selain itu, kurangnya motivasi responden juga kemungkinan terkait dengan pengetahuan terkait diet yang kurang sehingga kurang percaya pada diet yang dianjurkan.

Motivasi adalah suatu dorongan dari dalam diri seseorang yang menyebabkan orang tersebut melakukan kegiatan-kegiatan tertentu guna mencapai suatu tujuan. Pada dasarnya motivasi merupakan interaksi seseorang dengan situasi tertentu yang dihadapinya. Di dalam diri seseorang terdapat kebutuhan atau keinginan terhadap objek di luar seseorang tersebut. Oleh sebab itu motivasi adalah suatu alasan seseorang untuk bertindak dalam rangka memenuhi kebutuhan hidupnya (Notoatmodjo, 2010).

Motivasi yang masih rendah pada responden mungkin disebabkan oleh lama sakit pasien yang telah menahun serta kurangnya dukungan dari keluarga atau orang-orang di sekitarnya dalam melaksanakan diet DM. Pasien Diabetes Mellitus yang telah didiagnosis bertahun-tahun cenderung merasa bosan dan lelah dengan diet yang dilakukan. Pada saat-saat seperti inilah diperlukan motivasi dari orangorang luar baik keluarga, teman maupun petugas kesehatan untuk membangkit kembali semangat pasien dalam menjalani pengaturan diet DM.

Ahli Gizi diharapkan lebih proaktif pada saat memberikan konsultasi, tidak hanya memberikan konsultasi mengenai pengaturan makan pasien DM tetapi juga memberikan motivasi pada pasien untuk terus melaksanakan diet serta mengedukasi keluarga untuk selalu mendukung jalannya pelaksanaan diet DM bagi pasien.

\section{d. Gambaran Dukungan Keluarga Pasien Diabetes Mellitus}

Berdasarkan penelitian yang dilakukan di ruangan Poli Penyakit Dalam RSUD Dr. H. Abdul Moeloek terhadap pasien rawat jalan diabetes dapat diketahui bahwa sebagian besar pasien Diabetes Mellitus mendapat dukungan keluarga yang baik yaitu sebesar $66,7 \%$ sedangkan pasien dengan dukungan keluarga yang kurang baik hanya sekitar 33,3\%.

Dari wawancara dengan responden diketahui bahwa responden dengan keluarga yang mendukung sebanyak 66,7\%. Mayoritas keluarga mendukung karena mengetahui hal-hal yang terkait pengobatan dan diet yang harus dilakukan oleh responden serta telah bersama responden dalam waktu yang lama. Beberapa anggota keluarga juga menemani responden saat konseling sehingga pengetahuan mereka tentang diet cukup baik. Sebaliknya responden dengan dukungan keluarga yang kurang mendukung $(33,3 \%)$ terjadi kemungkinan karena ketidaktahuan keluarga mengenai diet yang harus dijalani responden sehingga tidak bisa menegur responden ketika tidak mematuhi anjuran diet yang diberikan.

Penelitian ini sejalan dengan penelitian yang dilakukan oleh Pratiwi dan Endang (2012) bahwa dukungan keluarga untuk pada pasien DM tipe 2 dengan kategori baik sebesar $70 \%$. Hal ini disebabkan karena sebagian besar pasien menderita DM cukup lama yang dapat dilihat dari kunjungan ulang yang dilakukan di rumah sakit sehingga anggota keluarga sudah memahami dan mengerti keadaan yang menimpa salah satu anggota keluarganya. Niven (2002) menyatakan bahwa dukungan keluarga dalam bentuk dukungan emosional dari anggota keluarga yang lain merupakan faktor yang penting dalam kepatuhan terhadap program diit yang dijalankan. Keluarga dapat membantu mengurangi ketidakpedulian yang disebabkan oleh penyakit 
tertentu dan mereka dapat menghilangkan godaan pada ketidaktaatan dan seringkali dapat menjadi kelompok pendukung untuk mencapai kepatuhan.

Peran aktif keluarga sangat dibutuhkan dalam proses pengobatan pasien diabetes karena salah satu pilar pengendalian diabetes adalah pengaturan makan atau biasa disebut diet. Peran keluarga sangat dibutuhkan untuk mengawasi serta mengingatkan pasien diabetes agar tidak melanggar aturan makan meskipun menginginkannya. Selain itu, keluarga juga berperan penting dalam hal emosional pasien diabetes. Pengobatan diabetes memiliki jangka waktu yang panjang karena diabetes merupakan penyakit yang tidak bisa disembuhkan sehingga diperlukan pengendalian yang tepat agar kadar gula darah terus terkontrol. Akibat pengobatan jangka panjang kemungkinan besar penderita diabetes merasa jenuh dan putus asa. Oleh karena itu, peran keluarga sangat penting untuk terus memotivasi serta mendukung anggota keluarga untuk terus menjalankan pengobatan dan diet yang disarankan.

\section{e. Gambaran Kepatuhan Diet Pasien Diabetes Mellitus}

Berdasarkan penelitian yang dilakukan di ruangan Poli Penyakit Dalam RSUD Dr. H. Abdul Moeloek terhadap pasien rawat jalan diabetes dapat diketahui bahwa masih banyak pasien Diabetes Mellitus yang tidak patuh dalam pelaksanaan diet yaitu sebesar $60 \%$ sedangkan yang patuh dalam melaksanakan diet Diabetes Mellitus adalah sebesar 40\%.

Dari wawancara diketahui bahwa lebih banyak responden yang belum mematuhi diet diabetes $(60 \%)$. Beberapa hal yang masih sering diabaikan oleh responden adalah tidak mengurangi konsumsi makanan yang manis meskipun telah menggunakan gula pengganti, jarang mengonsumsi sayuran, tidak berolahraga dan tidak mengontrol berat badan. Mayoritas dari responden telah mengalami komplikasi atau memiliki penyakit lain seperti hipertensi dan asam urat. Adanya komplikasi atau penyakit lain tersebut membuat pasien sering tidak mematuhi anjuran diet yang diberikan.

Dari hasil penelitian diketahui masih ada responden yang belum pernah sekalipun mengikuti konseling gizi $(36,7 \%)$ padahal konseling merupakan hal yang penting bagi penderita DM. Pasien yang rutin melakukan konseling akan lebih memahami tentang penyakitnya dibandingkan dengan pasien yang tidak pernah melakukan konseling. Penjelasan tentang penyebab sakit dan bagaimana pengobatannya dapat membantu meningkatkan kepercayaan pasien untuk melakukan konsultasi untuk selanjutnya dapat membantu meningkatkan kepatuhan.

Hasil penelitian ini sejalan dengan penelitian yang dilakukan Cahyati (2015) tentang hubungan tingkat pengetahuan diet Diabetes Mellitus dengan kepatuhan diet pada penderita Diabetes Mellitus tipe II di Dusun Karang Tengah Yogyakarta dimana hanya 3\% responden yang patuh terhadap diet, sedangkan yang tidak patuh terhadap diet sebanyak 97\%. Dalam penelitian, Cahyati (2015) menyimpulkan bahwa kepatuhan diet Diabetes Mellitus berkaitan dengan tingkat pengetahuan diet Diabetes Mellitus. Pengetahuan diet mempunyai pengaruh terhadap kepatuhan menjalani diet Diabetes Mellitus tipe II, ditunjukkan dengan sikap dan kepatuhan yang semakin membaik. Setiap penderita memerlukan waktu yang berbeda-beda dalam meningkatkan pengetahuan. Semakin banyak informasi yang didapat maka akan banyak pengetahuan yang diperoleh dan bisa bersikap positif terhadap kepatuhan diet Diabetes Mellitus.

Kepatuhan adalah suatu perilaku manusia yang taat terhadap peraturan, perintah, prosedur dan disiplin. Kepatuhan adalah tingkat perilaku pasien yang tertuju terhadap instruksi atau petunjuk yang diberikan dalam bentuk terapi apapun yang ditentukan, baik diet, latihan, pengobatan atau janji pertemuan dengan dokter. Keyakinan, sikap dan kepribadian juga sangat berpengaruh kepada kepatuhan pasien dalam pelaksanaan diet karena faktor tersebut adalah faktor internal dalam diri seseorang. Orang yang memiliki kepribadian yang pesimis akan mudah menyerah dalam menghadapi pengobatan serta pengaturan makan karena merasa bahwa pengobatan tersebut sangat sulit dilakukan. Karena itu, untuk orang yang memiliki kepribadian yang pesimis serta sikap yang negatif sangat membutuhkan motivasi dari luar seperti dukungan sosial dan dukungan keluarga (Niven, 2002).

\section{f. Hubungan Lama Sakit dengan Kepatuhan Diet Pasien Diabetes Mellitus}

Berdasarkan hasil penelitian yang telah dilakukan pada pasien Diabetes Mellitus rawat jalan di Poli Penyakit Dalam RSUD Dr. H. Abdul Moeloek dapat diketahui bahwa responden yang patuh terhadap diet adalah sebesar 33,3\% dengan lama sakit kurang dari 5 tahun dan $41,7 \%$ dengan lama sakit lebih dari sama dengan 5 tahun.

Hasil uji chi square menunjukkan tidak adanya hubungan yang bermakna antara lama sakit dengan tingkat kepatuhan diet pada pasien 
Diabetes Mellitus tipe II di RSUD Dr. H. Abdul Moeloek Provinsi Lampung Tahun 2016 dengan nilai $p=0,709(p<0,05)$.

Hal ini sejalan dengan penelitian Ferdiansyah (2014) dalam Gustina (2014) mengenai faktor-faktor yang berhubungan dengan tingkat kepatuhan diet pasien Diabetes Mellitus tipe 2 di wilayah kerja Puskesmas Ciputat Kota Tangerang Selatan dengan sampel berjumlah 33 orang yang menyatakan bahwa lama sakit tidak berhubungan dengan tingkat kepatuhan diet penderita DM.

Penelitian Bernal, dkk (2000) menemukan bahwa pasien yang telah lama menderita DM namun disertai komplikasi memiliki efikasi diri yang rendah. Dengan adanya komplikasi akan mempengaruhi kemampuan pasien untuk mengelola perawatan diri dan penyakitnya. Tingkat kepatuhan dengan durasi penyakit cenderung memiliki hubungan negatif. Semakin lama pasien menderita diabetes, semakin kecil kemungkinan untuk menjadi patuh terhadap pengobatan.

Sebaliknya, menurut Abrahim (2011) dalam tesisnya yang berjudul Studi Literatur Sistematis pada Faktor yang Berkontribusi untuk Perawatan Diri pada Pasien Diabetes Mellitus tipe 2 bahwa lama sakit pasien DM tipe II memiliki korelasi positif, dimana pasien yang telah lama menderita DM tipe 2 memiliki pengalaman serta telah belajar dari rasa sakit yang telah ia alami selama masa sakitnya sehingga kepatuhan pasien meningkat seiring berjalannya waktu.

\section{g. Hubungan Pengetahuan dengan Kepatuhan Diet Pasien Diabetes Mellitus}

Berdasarkan hasil penelitian yang telah dilakukan pada pasien Diabetes Mellitus rawat jalan di Poli Penyakit Dalam RSUD Dr. H. Abdul Moeloek dapat diketahui bahwa pasien Diabetes Mellitus tipe 2 yang patuh terhadap diet sebanyak $60 \%$ dengan pengetahuan yang baik dan tidak ada yang berpengetahuan kurang.

Hasil uji Fisher menunjukkan adanya hubungan yang bermakna antara tingkat pengetahuan dengan tingkat kepatuhan diet pada pasien Diabetes Mellitus di RSUD Dr. H. Abdul Moeloek Provinsi Lampung Tahun 2016 dengan nilai $p=0,002(p<0,05)$.

Dari hasil penelitian dapat dilihat bahwa tingkat pengetahuan mempengaruhi kepatuhan pasien dalam menjalankan diet. Pasien yang memiliki tingkat pengetahuan yang baik akan lebih patuh terhadap pelaksanaan diet sehari-hari, sedangkan pasien yang pengetahuannya kurang baik tidak patuh terhadap pelaksanaan diet sehari-hari.

Penelitian ini menunjukkan bahwa tingkat pengetahuan merupakan salah satu faktor yang kuat dalam mempengaruhi tingkat kepatuhan diet pada diabetisi di RSUD Dr. H. Abdul Moeloek Provinsi sehingga pemberian informasi yang mendalam tentang Diabetes Mellitus sangat penting untuk dilakukan agar tingkat kepatuhan diet pada pasien meningkat dan menurunkan terjadinya risiko keparahan penyakit dan komplikasi serta dapat mengontrol gula darah pada pasien Diabetes Mellitus.

Hasil penelitian ini sejalan dengan penelitian yang dilakukan oleh Raharjo (2015) mengenai hubungan pengetahuan dan sikap dengan kepatuhan diet Diabetes Mellitus pada penerita Diabetes Mellitus di Desa Gonilan dengan jumlah responden 45 orang yang menyimpulkan bahwa ada hubungan yang signifikan antara tingkat pengetahuan dengan kepatuhan diet $(p=0.001)$. Hal ini disebabkan karena responden umumnya telah mempunyai pendidikan yang baik, sehingga responden mampu untuk menangkap informasi tentang faktor yang mempengaruhi diabetes melitus yang terdapat di media cetak seperti koran, majalah, leafleat dan brosur. Sehingga responden dapat mengetahui pola makan untuk mengontrol kadar gula darah.

Bagi penderita Diabetes Mellitus, pengetahuan serta pemahaman tentang penyakit serta pengaturan makan sangat penting mengingat bahwa penderita diabetes harus selalu menjaga kadar gula darah dalam keadaan normal. Kadar gula darah akan terkontrol apabila pengetahuan pasien mengenai prinsip diet diabetes yaitu tepat jumlah, jadwal dan jenis baik maka pelaksanaan diet akan berpengaruh signifikan terhadap pengontrolan kadar gula darah yang tentu saja dibantu dengan pilar terapi diabetes lainnya yaitu latihan jasmani, obatobatan serta edukasi.

\section{h. Hubungan Motivasi Pasien dengan Kepatuhan Diet Pasien Diabetes Mellitus}

Berdasarkan hasil penelitian yang telah dilakukan pada pasien Diabetes Mellitus rawat jalan di Poli Penyakit Dalam RSUD Dr. H. Abdul Moeloek dapat diketahui bahwa responden yang patuh terhadap diet sebanyak $16,7 \%$ dengan motivasi yang kurang baik dan $83,3 \%$ dengan motivasi yang baik.

Hasil uji chi square menunjukkan adanya hubungan yang bermakna antara motivasi pasien dengan tingkat kepatuhan diet pada pasien Diabetes Mellitus di RSUD Dr. H. Abdul 
Moeloek Provinsi Lampung Tahun 2016 dengan nilai $p=0,004(p<0,05)$.

Dari hasil penelitian dapat disimpulkan bahwa motivasi pasien merupakan salah satu hal yang mempengaruhi pasien Diabetes Mellitus terhadap kepatuhannya dalam menjalani diet DM. Semakin baik motivasi pasien maka tingkat kepatuhan diet semakin tinggi. Sebaliknya, semakin rendah motivasi pasien maka tingkat kepatuhan diet semakin rendah.

Dari wawancara yang dilakukan, responden dengan motivasi yang tinggi serta patuh terhadap diet $(83,3 \%)$ menyatakan bahwa mereka percaya bahwa dengan menjalani diet tubuh mereka akan merasa lebih baik karena gula darah terus terkontrol. Hal ini berkaitan dengan pengetahuan mereka tentang diet DM yang baik serta mendapat dorongan motivasi dari luar seperti keluarga dan petugas kesehatan untuk mematuhi diet. Sebaliknya, responden dengan motivasi yang kurang serta tidak patuh dalam menjalani diet $(77,8 \%)$ menyatakan bahwa mereka telah lama menderita diabetes sehingga merasa bosan dengan diet yang dianjurkan sehingga motivasi dalam menjalani diet menurun.

Penelitian ini sejalan dengan penelitian yang dilakukan oleh Gustina (2014) mengenai faktor-faktor yang berhubungan dengan kepatuhan diet Diabetes Mellitus pada pasien DM dengan sampe sejumlah 70 orang yang menyatakan bahwa ada hubungan bermakna antara motivasi pasien dengan kepatuhan diet DM ( $\mathrm{p}=0,001)$. Menurut Hordget (2000) dalam Gustina (2014) motivasi adalah psikologis yang mendorong sekaligus mengendalikan seseorang secara langsung. Makna yang terkandung didalamnya yaitu dorongan dan motivasi dimana motivasi ini yang memegang peranan penting karena motivasi berisikan perilaku, artinya dalam konteks perubahan pola makan bagi pasien DM didasarkan pada keinginan pasien untuk sembuh dan mengurangi kecatatan akibat menderita DM sehingga mereka termotivasi untuk mengikuti program diet yang dianjurkan oleh dokter.

Motivasi diri adalah dorongan, baik dari dalam maupun dari luar diri manusia untuk menggerakkan dan mendorong sikap dan perubahan perilakunya. Motivasi ini didasarkan dari faktor internal individu yang bersifat psikologis dan sebagai akibat dari internalisasi dari informasi dan hasil pengamatan suatu objek yang melahirkan persepsi sehingga individu dapat terdorong untuk berbuat atau melakukan sesuatu (Setiadi, 2012).

Dorongan dan motivasi ini yang memegang peranan penting karena motivasi berisikan perilaku, artinya dalam konteks perubahan pola makan bagi pasien DM didasarkan pada keinginan pasien untuk sembuh dan mengurangi risiko komplikasi akibat menderita DM sehingga mereka termotivasi untuk mengikuti program diet yang dianjurkan oleh dietetisien.

\section{i. Hubungan Dukungan Keluarga dengan Kepatuhan Diet Pasien Diabetes Mellitus}

Berdasarkan hasil penelitian yang telah dilakukan pada pasien Diabetes Mellitus rawat jalan di Poli Penyakit Dalam RSUD Dr. H. Abdul Moeloek dapat diketahui bahwa responden yang patuh terhadap diet sebanyak $60 \%$ dengan dukungan keluarga yang mendukung, sedangkan responden dengan dukungan keluarga yang kurang tidak ada yang patuh terhadap diet.

Hasil uji Fisher menunjukkan adanya hubungan yang bermakna antara dukungan keluarga dengan tingkat kepatuhan diet pada pasien Diabetes Mellitus di RSUD Dr. H. Abdul Moeloek Provinsi Lampung Tahun 2016 dengan nilai $p=0,002(p<0,05)$.

Dari hasil penelitian ini menunjukkan bahwa dukungan keluarga yang baik akan mempengaruhi seseorang untuk menjalankan dan mematuhi diet yang dianjurkan. Semakin besar dukungan keluarga yang diberikan kepada penderita Diabetes Mellitus, maka semakin tinggi tingkat kepatuhan diabetisi dalam menjalankan diet yang diberikan.

Penelitian ini sesuai dengan pendapat Niven (2002) yang menyatakan bahwa dukungan keluarga dalam bentuk dukungan emosional dari anggota keluarga yang lain merupakan faktor yang penting dalam kepatuhan terhadap program diit yang dijalankan. Keluarga dapat membantu mengurangi ketidakpedulian yang disebabkan oleh penyakit tertentu dan mereka dapat menghilangkan godaan pada ketidaktaatan dan seringkali dapat menjadi kelompok pendukung untuk mencapai kepatuhan.

Penelitian ini sejalan dengan penelitian yang dilakukan oleh Pratiwi dan Endang (2012) mengenai hubungan dukungan keluarga dengan kepatuhan diit pada pasien Diabetes Mellitus tipe 2 rawat jalan di RSUD dr. Soediran Mangun Sumarso dengan jumlah sampel 30 orang yang menyatakan bahwa ada hubungan dukungan kelurga dengan ketepatan jumlah, jadwal dan jenis makanan penderita diabetes $(\mathrm{p}=0,000)$.

Kendala utama pada penanganan diet Diabetes Mellitus adalah kejenuhan pasien dalam mengikuti terapi diet yang sangat diperlukan untuk mencapai keberhasilan. Pelaksanaan diet Diabetes Mellitus sangat dipengaruhi oleh adanya dukungan dari keluarga. Dukungan dapat 
digambarkan sebagai perasaan memiliki atau keyakinan bahwa seseorang merupakan peserta aktif dalam kegiatan sehari-hari. Perasaan saling terikat dengan orang lain di lingkungan menimbulkan kekuatan dan membantu menurunkan perasaan terisolasi (Brunner \& Suddart, 2002).

Dukungan keluarga diartikan sebagai bantuan yang diberikan oleh anggota keluarga yang lain sehingga akan memberikan kenyamanan fisik dan psikologis pada orang yang dihadapkan pada situasi stres. Dukungan sosial keluarga adalah proses yang terjadi selama masa hidup, dengan sifat dan tipe dukungan sosial bervariasi pada masing-masing tahap siklus kehidupan keluarga. Walaupun demikian, dalam semua tahap siklus kehidupan, dukungan sosial keluarga memungkinkan keluarga berfungsi secara penuh dan dapat meningkatkan adaptasi dalam kesehatan keluarga (Carpenito, 2000).

Berdasarkan penelitian yang telah dilakukan dapat dikatakan bahwa peran keluarga sangat penting dalam pengaturan diet pada penderita Diabetes Mellitus. Dukungan keluarga yang sangat dibutuhkan oleh penderita diabetes adalah berupa pengawasan dan dukungan dalam menjalankan diet yang dianjurkan serta tidak melanggar diet yang diberikan. Selain itu, hendaknya keluarga selalu memberi semangat kepada diabetisi untuk terus berjuang dan bersemangat dalam mengahadapi penyakitnya serta selalu mendengarkan keluh kesah diabetisi agar segi psikologisnya selalu tenang dan terhindar dari stres yang justru akan memperburuk kondisi kesehatan diabetisi.

\section{SIMPULAN}

Hasil penelitian ini menunjukkan tidak ada hubungan antara lama sakit dengan kepatuhan diet pasien Diabetes Mellitus ( $p$-value $=0,709$ ). Untuk variable lain terdapat hubungan yang bermakna yaitu tingkat pengetahuan dengan kepatuhan $\operatorname{diet}(p$-value $=0.002)$, motivasi pasien dengan kepatuhan diet (pvalue:0,004), dukungan keluarga dengan kepatuhan diet pasien Diabetes Mellitus ( $p$-value $=0,002$ ).

\section{SARAN}

Berdasarkan kesimpulan di atas, peneliti memberikan beberapa saran antara lain:

1. Bagi Rumah Sakit diharapkan meningkatkan kerjasama antara dokter dan ahli gizi untuk meningkatkan pengetahuan dan kesadaran pasien dengan mengadakan penyuluhan gizi khususnya untuk pasien Diabetes Mellitus tipe 2 dalam pengaturan makan serta merujuk pasien Diabetes Mellitus ke Poli Gizi apabila pengetahuan pasien terkait pengaturan makan masih dirasa kurang. Selain itu diperlukan peran ahli gizi untuk lebih aktif dalam memberikan pelayanan pada saat konsultasi gizi sehingga pasien berminat untuk datang ke konsultasi gizi.

2. Bagi Ahli Gizi diharapkan lebih proaktif pada saat memberikan konsultasi. Ahli Gizi diharapkan tidak hanya memberikan konsultasi mengenai pengaturan makan pasien DM tetapi juga memberikan motivasi pada pasien untuk terus melaksanakan diet serta mengedukasi keluarga untuk selalu mendukung jalannya pelaksanaan diet DM bagi pasien.

\section{DAFTAR PUSTAKA}

Abrahim, Mehammedsrage. 2011. Self-Care in Type 2 Diabetes: A Systematic Literature Review on Factors Contributing to SelfCare among Type 2 Diabetes Mellitus Patients. Tesis. Linnaeus University.

Bernal, H., dkk. 2000. Correlates of selfefficacy in diabetes self-care among Hispanic adults with diabetes. The Diabetes Educator 2000; volume 26; number 4. http://tde.sagepub.com/cgi/reprint/

(Diunduh tanggal 10 Juli 2016)
Brunner \& Suddarth. 2002. Keperawatan Medical Bedah. Vol.2. Jakarta: EGC.

Bilous, Rudy \& Richard Donelly. 2014. Buku Pegangan Diabetes. Edisi ke-4. USA: John Willey \& Sons Limites. Diterjemahkan oleh Egi Komara Yuda, S.Kp.,MM

Cahyati, Suci Mei. 2015. Hubungan Tingkat Pengetahuan Diet Diabetes Mellitus dengan Kepatuhan Diet pada Penderita Diabetes Mellitus Tipe II di Dusun Karang Tengah, Yogyakarta. Yogyakarta: STIKES Aisyiyah Yogyakarta. 
Carpenito, L.J. 2000. Diagnosa keperawatan; Aplikasi pada praktik klinis. Edisi 6. Jakarta: EGC.

Ferdiansyah, Randi. 2014. Hubungan Asupan Serat dan Zink dengan Kadar Gula Darah pada Pasien Diabetes Mellitus Tipe 2 di Poli Penyakit Dalam RSUD Abdul Moeloek Tahun 2014. Karya Tulis Ilmiah. Politeknik Kesehatan Tanjung Karang: Lampung.

Gustina dkk. 2014. Faktor-faktor yang Berhubungan dengan kepatuhan Diet Diabetes Mellitus pada Pasien DM. Jurusan Keperawatan Poltekkes Kemenkes Jakarta III: Jakarta.

Hiswani. 2010. Peranan Gizi Dalam Diabetes Mellitus. Fakultas Kedokteran Universitas Sumatera Utara (Diunduh pada 19 Desember 2015).

Indarwati, Dewi dkk. 2012. Hubungan Motivasi Dengan Kepatuhan Diet Diabetes Melitus Pada Pasien Diabetes Melitus Di Desa Tangkil Wilayah Kerja Puskesmas Kedungwuni II Kabupaten Pekalongan. Prodi S1 Keperawatan STIKES Pekajangan Pekalongan

Kemenkes RI. 2014. Situasi dan Analisis Diabetes. Kemenkes RI: Jakarta.

Niven, Neil. 2002. Psikologi Kesehatan. Edisi 2. Jakarta; Penerbit Buku Kedokteran EGC.

Notoatmodjo, S. 2003. Pendidikan dan Perilaku Kesehatan. Jakarta: PT. Rineka Cipta. Jakarta: Rineka Cipta.
Nursalam. 2011. Manajemen Keperawatan. Edisi 3. Jakarta: Salemba Medika.

Pratiwi, Ambar, dan Endang. 2012. Hubungan Tingkat Pengetahuan, Sikap, dan Dukungan Keluarga dengan Tingkat Kepatuhan Diet Diabetes Mellitus Tipe 2 di Ruang Rawat Inap RSUD Dr.H. Abdul Moeloek Provinsi Lampung Tahun 2012. Karya Tulis Ilmiah. Jurusan Gizi Politeknik Kesehatan Tanjung Karang: Lampung.

Rahmat, Jalaludin. 2002. Psikologi Komunikasi. Edisi Revisi. Bandung: PT. Remaja Rosdakarya.

Raharjo, Annas Sigit. 2015. Hubungan Tingkat Pengetahuan dan Sikap dengan Kepatuhan Diet Diabetes Melitus Pada Penderita Diabetes Melitus di Desa Gonilan. Surakarta: Universitas Muhammadiyah Surakarta.

Setiadi. 2012. Konsep \& Penulisan Dokumentasi Asuhan Keperawatan Teori dan Praktik. Yogyakarta: Graha Ilmu.

Suyono, Slamet dkk. 2015. Penatalaksanaan Diabetes Mellitus Terpadu. Jakarta: Badan Penerbit FKUI.

Syafputri. 2012. Pakar : diabetes mulai banyak menyerang usia muda. http://www.antaranews.com/ (Diakses pada tanggal 12 Juli 2016).

Wade \& Travis. 2007. Psikologi. ed. 9. Jakarta: Erlangga. 